Article

\title{
The Role of Institutional Ownership and Industry Characteristics on the Propensity to Pay Dividend: An Insight from Company Open Innovation
}

\author{
S. Martono *, Arief Yulianto, Rini Setyo Witiastuti and Angga Pandu Wijaya \\ Department of Management, Universitas Negeri Semarang, Semarang 50229, Indonesia; \\ ariefyulianto@mail.unnes.ac.id (A.Y.); witiastuti@mail.unnes.ac.id (R.S.W.); apwijaya@mail.unnes.ac.id (A.P.W.) \\ * Correspondence: martono@mail.unnes.ac.id
}

Received: 14 July 2020; Accepted: 29 August 2020; Published: 3 September 2020

\begin{abstract}
The purpose of this study is to test the free cash flow agency theory hypothesis; namely, (a) whether differences in industrial sector affect a company's propensity to pay dividends, and (b) whether institutional ownership is able to substitute for the propensity to pay dividends as a bonding mechanism. The analysis uses logistic regression to explore the existence of institutional ownership as a substitute for paying cash dividends in companies belonging to different industrial sectors. The results show that companies in the manufacturing sector have a greater propensity to pay dividends compared to those in non-manufacturing sectors. The results also indicate that low institutional ownership, as an external monitoring mechanism, can substitute for increasing the propensity to pay dividends. Overall, the results are consistent with implications in dividend policy. The results support the notion that the propensity to pay dividends accommodates different behavioral factors, considering sectoral differences. In addition, the results illustrate the relevance of alternative theories in explaining dividend policy from the perspective of agency theory. The results show that sectoral comparisons, in addition to institutional ownership factors, play important roles in the propensity of Indonesian companies to pay dividends. This study shows that each industry sector has different income characteristics, which affect the differences in propensity to pay dividends.
\end{abstract}

Keywords: propensity to pay dividend; industry sectors; Institutional ownership

\section{Introduction}

Benefits are an essential factor that push the relationship between agency problems and free cash flow. Agents have a high propensity to maximize their benefit; however, if a conflict arises, the agent will prioritize their interests. Conflicts of interest appear due to significant differences in interest [1]. Agency problems occur due to differences in the interests of managers and shareholders in using free cash flow (FCF). Easterbrook argued that there are two causes of agency problems [2]: (a) shareholders preference for using FCF for investments with high returns despite a high level of risk, and opting to monitor the managers' investment decisions; (b) managers dislike of risk, which prompts them to allocate FCF for investments with low risk. It is suspected that FCF is the cause of agency problems between managers and shareholders.

Based on actual data, agency problems are not limited to disagreements between managers and shareholders but also between shareholders and debtholders. A manager who concurrently acts as a shareholder would have both the rights and control over their cash flow. Thus, they are more likely to make suboptimal investments [3]. Value transfer from debtholder to shareholder is ensued. They utilize debt to select suboptimal investment that is oriented to increasing equity value instead of company value. This situation could lead to overinvestments based on exaggerated decision [4]; 
human resource management development [5]; over confidence [6], and underinvestment due to moral hazard and asymmetric information [7]; the selling of additional assets [8].

Risk shifting, resulting from overinvestment, after debt contract will transfer to the higher risk investment. Hence, the debt market value undergoes devaluation. A manager who is a shareholder and another shareholder face less debt than they should when the beta is not adjusted. Shareholders obtain equity value growth benefits from risk shifting when a project is accomplished, and share risks with debtholders when the project fails. A contradictory situation appears when companies conduct risk avoidance and rejects projects with a positive net present value (NPV), provided that it is not significantly beneficial to shareholders. As a result, debtholders will increase lending rates and reduce lending, therefore complying with funding through the capital market. This situation results in higher premium demands from new shareholders due to self-protection in manager's behavior, and the equity value declines due to dilution. Furthermore, in a project unable to be financed with equity, there is a conflict between current shareholders and previous shareholders.

Debt usage results in increasing suboptimal investment risk, therefore debt utilization is expected to reduce discretional power in FCF, for managers' as shareholders' benefit. In addition, instead of debt, dividends are fruitful to reduce FCF [1]. Research on 669 units of observation in Vietnamese concluded that debt and dividends are substitution variables that could mediate between overinvestment and firm performance [9]. The impact of debt is more treacherous to the company, which leads to financial difficulties and bankruptcy, whereas cutting dividends will only reduce equity value. This situation encourages further understanding of substituted factors of dividends, considering weak minority investor protection in developing countries [4], such as Indonesia.

When a manager receives an incentive for each project, having excess cashflow in investments with a positive net present value (NPV) could result in the allocation of funds to unprofitable projects [1]. Larger FCF could potentially trigger more problems between the manager and shareholders. Therefore, it is necessary to consider the role of substitution between dividends as a bonding mechanism, and institutional ownership as a monitoring mechanism. FCF is the remaining cash within a company once all investment projects with positive NPV have been implemented [1]. Therefore, the use of FCF has the potential to cause agency conflicts, occurring between managers (agents) and shareholders (principals). FCF can be used by companies as dividends, to reduce debt or issue equity, or as precautionary savings or additional investments [10].

A previous study identified free cash flow as one source of agency problems between managers and shareholders [11]. Managers of firms with high FCF and low growth opportunities tend to invest in marginal or even negative NPV projects and use income-increasing discretionary accruals to camouflage the effects of non-wealth-maximizing investments. FCF is determined by the characteristics of the industrial sector to which a given company belongs, which have differing characteristics and business scopes. FCF differences by industrial sector lead to variations in agency problems, such that dividends as bonding mechanisms differ $[12,13]$.

In addition to dividends in the FCF hypothesis, institutional ownership can serve as a substitute to reduce agency problems. Companies with institutional ownership have the capability and resources to monitor agency problems [6]. Studies that have been conducted show that monitoring could reduce agency problems. More specifically, institutional ownership as a monitoring device, has a significant positive correlation with dividends [14-16]. In contrast, another piece of research explains that, from the signaling hypothesis perspective, institutional ownership is negatively correlated to dividends because they make it unnecessary to monitor the capital market for agency problems. Furthermore, different industrial sectors result in different FCF, agency problems, and impacts of using dividends as monitoring devices [17]. However, based on the signaling perspective, dividends are triggered by other companies in the intra-industry.

This paper investigates how industrial sectors and institutional ownership affects dividends. We use logistic regression to discover how agency problems and signaling hypothesis variations in the industrial sector affect dividends. Furthermore, we also test the role of institutional ownership. 
Previous studies have predicted dividends using ordinary least square (OLS) and generalized least squares (GLS), techniques used for estimating the unknown parameters in a linear regression model when there is a certain degree of correlation between the residuals in the regression model. The research proposes that the differences between industrial sectors impact the differences in the propensity to pay dividends. Companies with low institutional ownership have an increased propensity to pay dividends and vice versa.

\section{Literature Review}

\subsection{FCF Hypothesis: Institutional Ownership, Industry Sector, and Dividends}

Agency problems escalate as free cash flow increases. This stage occurs when a company is in the growth stage. A higher percentage of dividends diminishes fund availability. Therefore, managers tend to restore free cash, becoming more reluctant to use funds carelessly [1]. When a company needs external funding (equity) and has a risky debt as a monitoring device, it tends to increase its dividend payment propensity. The dividend not only acts as a monitoring device, but also helps in decreasing agency costs that cover managers' consumption of perks and overinvestment [1]. However, institutional shareholders are unlikely to be involved directly in monitoring, because they typically have long-term investment planning [18]. Moreover, institutional shareholders tend to suggest that companies pay higher dividends and, for financial needs, seek future external capital markets. Investors with institutional ownership conduct strict monitoring of the company and expect reward in the form of large dividends. Agency cost is related to free cash flow and overinvestment [19]. Higher institutional ownership increases capital market monitoring activities, resulting in bigger dividends. A previous study reinforced the notion that institutional ownership causes an escalation in company monitoring [20].

Based on the FCF hypothesis, it can be concluded that investors would like to make their institutional ownership more intensive, because monitoring the company's actual income status would lead to a more substantial shareholding. As a result, institutional investors take a critical role in governing corporations that seek to receive more dividends. Managers as shareholders have discretional power in determining the use of FCF, which could result in suboptimal investments. This prediction is based on the overinvestment hypothesis due to risk factors [1], and an underinvestment presumption due to assets ownership and growth opportunities [7]. Future studies are advised to explore these overinvestment and underinvestment factors because they could differ across types of industries. Firms with a larger size, higher interest coverage ratio, profitability, and low business risk and debts are likely to distribute higher dividends in India [17]. The profitability of an institution could indicate the applicability of the free cash flow hypothesis in India. Growth opportunities and FCF differ between sectors in the Indian capital market.

The type of risk that managers tend to avoid is within the area of FCF allocation. As one of the causes of agency problems, FCF can be caused by differences in the scope of business and operations in the industrial sector. FCF refers to the excess money that a company generates in a given project [1]. This cash could be used to cover dividends, debts, and sweeteners when issuing equity, to retain it as precautionary savings, or as additional investments. A study conducted in Jordan described that industrial sectors impact FCF, but that these types of sectors do not impact dividend decisions [21]. The consumer noncyclical industry sector seeks to maintain a higher FCF than other industries (e.g., the aviation industry). Previous research explained that agency cost does not significantly influence dividend decisions in various industrial sectors [22]. In the basic industry sector, companies with high FCF tend to pay lower dividends [23].

Prior research highlighted that companies in the diversified, industrial, and basic materials industries in the US tend to pay lower dividends [12]. Previous research described different dividend payments in the manufacturing sector. Dividend payments in the manufacturing sector and the miscellaneous sector were higher compared to other sectors. The shipping sector tends to have large 
debts due to the high demand for using FCF for investment in ship facilities and fixed assets [24]. Considering that dividend regulations vary, the current study conducted a proxy to the proportion of pay dividends. Additionally, the proxy of cash dividends is used in this study to account for the inconsistent literature results concerning the causes of dividend distribution.

A study of non-financial companies listed on the Abu Dhabi Securities Exchange discovered that dividends are positively associated with income and negatively associated with leverage, although differences do exist between sectors [25]. These sectors include the manufacturing, telecommunications, service, food, energy, telecommunications, and property and real estate sectors. Institutional ownership acts as a signaling device for dividends, particularly to reduce information asymmetry. It signals two conditions: (1) better insight regarding the company's future growth due to having access to direct monitor resources, and (2) a positive mechanism to reduce agency problems [16]. Several studies also added that dividend policy is negatively and significantly associated with institutional ownership [26,27].

Without perilous debt, the provision of sweeteners (i.e., dividends) will be marked as positive news for the market. Namely, that the value of equity will increase. This condition could lead to improvements in the monitoring of the capital market. However, institutional shareholders (e.g., pension funds, insurance companies, investment companies, and banks) can carry out better monitoring, contributing to reducing the propensity to pay dividends. Therefore, dividends and institutional ownership are substitutes [28]. Companies do not need to pay dividends if institutional investors' presence alleviates concerns, if management dissipates the company's FCF. Investors could allocate more resources to monitoring company's management, and to comprehensively analyzing company's prospects [29].

The difference between FCF and the signaling hypothesis lies in the role that institutional ownership has on dividends. Based on the FCF hypothesis, the use of debt to limit managers' use of FCF increases the risk of financial difficulty and bankruptcy instead of suboptimal investment. Companies that need external funding will access the capital market, causing institutional ownership with better monitoring resources to ask for more dividends. In contrast, the signaling hypothesis explains that institutional ownership can substitute dividends as a monitoring mechanism because companies can monitor their resources better. Thus, the present study formulates the first hypothesis: institutional ownership affects company's dividend policy with a different direction of relationship between the FCF and the signaling hypothesis. For the first hypothesis, earning per share (EPS), the control variable, is used as a proxy for corporate income. The decision to use EPS as the control variable was made because EPS is considered as a signal in the signaling hypothesis.

\subsection{Signaling Hypothesis: Institutional Ownership, Industry Sector, and Dividends}

From the perspective of the FCF hypothesis, the cause of agency problems lies in the way that dividends can limit discretionary power. In this situation, management can act in its own interest, in contrast to the signaling hypothesis. Dividend information can sometimes be rejected by the market due to information asymmetry, leading to an unfavorable response from the investors. It has become a consensus among the academic and financial communities that managers have more, and superior information than other interested parties. The manager may use dividends as a signal to be conveyed to the market. Previous signaling research does not support the FCF hypothesis or wealth transfer hypothesis. The distribution of FCF to shareholders only increases the prosperity of the shareholders and does nothing for corporate profits [30]. Due to information asymmetry, manager incentives are needed when giving real information from the market [31]. Dividends tend to be viewed as good news as compared to bad news [32]. This situation shows the market reaction changes as expected.

As shareholders with suboptimal investment, managers can be inhibited from reducing FCF through debt and dividends. Companies prefer dividends because they are less risky than debt, although it depends on the company's characteristics, which are attached to the industrial sector. Previous research explained that companies with high FCF do not always distribute dividends, like investment opportunities and growth opportunities. Similarly, companies with low FCF also do 
not regularly distribute dividends. This situation indicates that the use of FCF does not entirely cause agency problems, but instead depends more on the characteristics of the industry and country. In other words, dividends as a substitute for debt cannot always be used in all general conditions but are more dependent on industry characteristics.

The signaling hypothesis is different from the FCF hypothesis. Theoretically, with asymmetric information, the signaling hypothesis explains that dividends could be utilized to send information to the market. Research on intra- and inter-industry relations with dividends is currently limited. A previous study found that dividend policies relate to the dividend policies upheld by external companies [33], with the relationship being: (a) positively related, (b) no relationship, and (c) negatively related to other companies. Meanwhile, dividend policy depends on industry specifications, so it does relate to the FCF agency problem. Research in the general, financial, and energy sectors, with the results in the energy industry having a contagion effect (contagious), showed dividend announcements made one company will be followed by another company, but not in the general sector [34].

The second hypothesis cannot apply the use of a control variable due to the heterogeneity of the company's characteristics in each industry. This consideration is essential partly because the use of FCF will differ profoundly depending on the company's characteristics, be it an intra- or inter-industry company. Additionally, both types of past study (i.e., with or without control variables) have discovered that a firm's nature does not significantly impact company performance [35]. This situation indicates that the company's environment or nature cannot be measured clearly.

\subsection{Shifting from Closed Innovation to Open Innovation}

Closed innovation (CI) is a linear model of an organization's dependence on internal competencies, such as strategy and processes, as well as research and development (R\&D), value, and idea creation practices. Researchers working at a CI company are designing and developing products according to customer needs. Rarely or never are new inventions the aftermath of closed innovation. This results in the perspective of innovation as an isolated process, due to the mechanism of creating values and ideas depending on the internal capacity of certain individuals and small groups within the company [36]. This situation encourages the company to use its internal competence independently for $R \& D$, to produce and use distribution channels to convey values and ideas to the market in situations of uncertainty and company limitations. The situation of uncertainty drives a paradigm shift from CI to open innovation (OI) through conceptualizing and commercializing inventions, therefore there are no company boundaries and this allows integrating several external parties such as universities, research organizations, suppliers, customers, and competitors in the innovation process [37]. The transition from the authoritative and individualistic innovative processes in the CI model to the open innovation (OI) model is currently required in the organization, and prominently in financial management [38].

Company characteristics, such as ownership structure, the industry the company operates in, and size determine involvement in open innovation [39]. The type of company ownership affects $R \& D$ policy. Each type of ownership has a different perspective regarding incentives, investment horizons, abilities to monitor, and control firm management, including R\&D decisions in closed or open innovation [40]. The research sample involves large companies listed on the Indonesia Stock Exchange, which have stronger R\&D competencies compared to SMEs (Small Medium-sized Enterprises) [39,41]. Larger companies that have sufficient $R \& D$ resources tend to disclose and commercialize OI more than SMEs with limited resources. Companies with corporate or institutional ownership have more external cooperation capabilities resulting in more adaptions for OI than companies with private ownership [42]. Private companies have limited financial, technology, and knowledge resources, which restricts innovation [43]. The benefits of OI for manufacturing companies listed on the New York Stock Exchange are profitability, production processes, improvements, and market profit [44]. There is a potential relationship between long-term shareholders value and open innovation in companies that pay dividends for more than 60 years [45]. Companies that practice OI can create higher value through dividends, and further encourage positive reactions from shareholders [44]. 
Open innovation is useful for organizational dynamics, especially for improving company performance [46]. When the company's performance increase, especially in terms of increasing revenue, shareholders expect higher returns through dividends. The prospects of the company are the primary attraction for an investor to invest in a company. Open innovation is an exertion that continues to grow, especially in companies through R\&D and business model development [47]. The key to the success of open innovation is located in the collaboration that is achievable through a combination of organizational resources [48]. The relationship between divisions within a company aims to achieve company goals and targets based on the vision and mission. Open Innovation is a strategy that is fruitful to achieve these targets and objectives of company revenue. The relationship between shareholders and the company is reciprocal. Shareholders increase company ownership through the capital market investment. Shareholders require delineated and comprehensive effort to monitor a company due to their interest in maintaining a profit. Open innovation is directly related to finance and policy dynamics related to the company's vision and mission [49]. Open innovation needs to involve a quadruple helix, which consists of researchers and technology infrastructures, company, government, and society, to produce significant innovations [50].

\section{Data and Methodology}

Table 1 depicts the data of the study. The data consists of 2596 company observations listed on the Indonesian Stock Exchange (IDX) between 2011 and 2018, specifically regarding their institutional ownership and shared cash dividends per share. The amount of data for each period has the same distribution tendency. The institutional ownership and debt-equity ratio are measured by the ratio of shares held by the institutional ownership, to the total number of outstanding shares [51] and cash dividends per share (DPS), recognized from the firm annual reports. Dividends are considered to be closely related to propensity to pay. Despite the fact that dividends are mandatory, this regulation could not be implemented in Indonesia because policies regarding the matter rely heavily on ownership and company structure [52].

Table 1. Number of companies per period and per sector.

\begin{tabular}{|c|c|c|c|c|c|c|c|c|c|c|c|}
\hline \multirow{2}{*}{ Code } & \multirow{2}{*}{ Sectors } & \multirow{2}{*}{ Sub-Sectoral } & \multicolumn{9}{|c|}{ Years } \\
\hline & & & 2011 & 2012 & 2013 & 2014 & 2015 & 2016 & 2017 & 2018 & Total \\
\hline 11 & Agriculture & Crops & 2 & 2 & 1 & 1 & 1 & 1 & 1 & 1 & 10 \\
\hline 12 & Agriculture & Plantation & 8 & 10 & 14 & 11 & 15 & 13 & 13 & 16 & 100 \\
\hline 13 & Agriculture & Animal Husbandry & 0 & 0 & 0 & 0 & 0 & 0 & 0 & 0 & 0 \\
\hline 14 & Agriculture & Fishery & 2 & 2 & 2 & 3 & 3 & 2 & 1 & 2 & 17 \\
\hline 15 & Agriculture & Forestry & 0 & 0 & 0 & 0 & 0 & 1 & 0 & 0 & 1 \\
\hline 19 & Agriculture & Others & 1 & 0 & 0 & 0 & 0 & 0 & 0 & 0 & 1 \\
\hline 21 & Mining & Coal Mining & 12 & 16 & 13 & 11 & 17 & 13 & 16 & 18 & 116 \\
\hline 22 & Mining & $\begin{array}{l}\text { Crude Petroleum and Natural } \\
\text { Gas Production }\end{array}$ & 4 & 5 & 4 & 5 & 6 & 4 & 7 & 9 & 44 \\
\hline 23 & Mining & Metal and Mineral Mining & 6 & 7 & 7 & 5 & 6 & 9 & 7 & 6 & 53 \\
\hline 24 & Mining & Land/Stone Quarrying & 1 & 2 & 1 & 2 & 2 & 2 & 1 & 1 & 12 \\
\hline 29 & Mining & Others & 0 & 0 & 0 & 0 & 0 & 0 & 0 & 0 & 0 \\
\hline 31 & Basic Industry and Chemicals & Cement & 3 & 1 & 3 & 2 & 4 & 5 & 5 & 6 & 29 \\
\hline 32 & Basic Industry and Chemicals & Ceramics, Glass, Porcelain & 5 & 6 & 6 & 5 & 6 & 4 & 5 & 6 & 43 \\
\hline 33 & Basic Industry and Chemicals & Metal and Allied Products & 11 & 11 & 14 & 10 & 14 & 11 & 11 & 10 & 92 \\
\hline 34 & Basic Industry and Chemicals & Chemicals & 6 & 7 & 9 & 7 & 8 & 8 & 9 & 9 & 63 \\
\hline 35 & Basic Industry and Chemicals & Plastics and Packaging & 11 & 9 & 9 & 10 & 10 & 9 & 10 & 12 & 80 \\
\hline 36 & Basic Industry and Chemicals & Animal Feed & 1 & 3 & 3 & 2 & 4 & 4 & 5 & 3 & 25 \\
\hline 37 & Basic Industry and Chemicals & Wood Industries & 1 & 1 & 2 & 2 & 1 & 1 & 1 & 2 & 11 \\
\hline 38 & Basic Industry and Chemicals & Pulp and Paper & 8 & 3 & 4 & 6 & 9 & 8 & 7 & 8 & 53 \\
\hline 39 & Basic Industry and Chemicals & Others & 0 & 0 & 0 & 0 & 0 & 1 & 2 & 1 & 4 \\
\hline 41 & Miscellaneous Industry & $\begin{array}{l}\text { Machinery and Heavy } \\
\text { Equipment }\end{array}$ & 0 & 0 & 0 & 1 & 13 & 2 & 3 & 3 & 22 \\
\hline 42 & Miscellaneous Industry & Automotive and Components & 9 & 7 & 8 & 6 & 0 & 10 & 12 & 11 & 63 \\
\hline
\end{tabular}


Table 1. Cont.

\begin{tabular}{|c|c|c|c|c|c|c|c|c|c|c|c|}
\hline \multirow{2}{*}{ Code } & \multirow{2}{*}{ Sectors } & \multirow{2}{*}{ Sub-Sectoral } & \multicolumn{9}{|c|}{ Years } \\
\hline & & & 2011 & 2012 & 2013 & 2014 & 2015 & 2016 & 2017 & 2018 & Total \\
\hline 43 & Miscellaneous Industry & Textile, Garment & 12 & 12 & 16 & 11 & 16 & 13 & 12 & 16 & 108 \\
\hline 44 & Miscellaneous Industry & Footwear & 1 & 1 & 2 & 0 & 2 & 2 & 2 & 2 & 12 \\
\hline 45 & Miscellaneous Industry & Cable & 4 & 4 & 4 & 3 & 4 & 6 & 6 & 6 & 37 \\
\hline 46 & Miscellaneous Industry & Electronics & 0 & 0 & 1 & 0 & 0 & 0 & 0 & 1 & 2 \\
\hline 49 & Miscellaneous Industry & Others & 0 & 0 & 0 & 0 & 0 & 0 & 0 & 0 & 0 \\
\hline 51 & Consumer Goods Industry & Food and Beverages & 11 & 13 & 13 & 9 & 13 & 14 & 18 & 15 & 106 \\
\hline 52 & Consumer Goods Industry & Tobacco Manufacturers & 3 & 3 & 3 & 3 & 3 & 4 & 3 & 3 & 25 \\
\hline 53 & Consumer Goods Industry & Pharmaceuticals & 6 & 8 & 9 & 7 & 8 & 8 & 8 & 9 & 63 \\
\hline 54 & Consumer Goods Industry & Cosmetics and Household & 4 & 6 & 4 & 5 & 6 & 6 & 6 & 5 & 42 \\
\hline 55 & Consumer Goods Industry & Houseware & 3 & 0 & 3 & 2 & 3 & 3 & 4 & 4 & 22 \\
\hline 59 & Consumer Goods Industry & Others & 0 & 0 & 0 & 0 & 0 & 0 & 1 & 0 & 1 \\
\hline 61 & $\begin{array}{l}\text { Property, Real Estate and } \\
\text { Building Construction }\end{array}$ & Property and Real Estate & 27 & 32 & 32 & 30 & 36 & 30 & 35 & 40 & 262 \\
\hline 62 & $\begin{array}{l}\text { Property, Real Estate and } \\
\text { Building Construction }\end{array}$ & Building Construction & 5 & 7 & 8 & 6 & 8 & 9 & 14 & 12 & 69 \\
\hline 69 & $\begin{array}{l}\text { Property, Real Estate and } \\
\text { Building Construction }\end{array}$ & Others & 0 & 0 & 0 & 0 & 0 & 0 & 0 & 0 & 0 \\
\hline 71 & $\begin{array}{l}\text { Infrastructure, Utilities and } \\
\text { Transportation }\end{array}$ & Energy & 2 & 2 & 2 & 1 & 4 & 5 & 5 & 5 & 26 \\
\hline 72 & $\begin{array}{l}\text { Infrastructure, Utilities and } \\
\text { Transportation }\end{array}$ & $\begin{array}{l}\text { Toll Road, Airport, Harbor, and } \\
\text { Allied Products }\end{array}$ & 1 & 2 & 3 & 2 & 2 & 2 & 4 & 5 & 21 \\
\hline 73 & $\begin{array}{l}\text { Infrastructure, Utilities and } \\
\text { Transportation }\end{array}$ & Telecommunication & 5 & 5 & 5 & 2 & 4 & 4 & 5 & 4 & 34 \\
\hline 74 & $\begin{array}{l}\text { Infrastructure, Utilities and } \\
\text { Transportation }\end{array}$ & Transportation & 14 & 20 & 20 & 18 & 23 & 22 & 24 & 30 & 171 \\
\hline 75 & $\begin{array}{l}\text { Infrastructure, Utilities and } \\
\text { Transportation }\end{array}$ & Non Building Construction & 4 & 4 & 5 & 4 & 6 & 7 & 8 & 12 & 50 \\
\hline 79 & $\begin{array}{l}\text { Infrastructure, Utilities and } \\
\text { Transportation }\end{array}$ & Others & 0 & 0 & 0 & 0 & 0 & 0 & 0 & 0 & 0 \\
\hline 91 & Trade, Services and Investment & $\begin{array}{l}\text { Wholesale (Durable and } \\
\text { Non-Durable Goods) }\end{array}$ & 24 & 22 & 26 & 23 & 27 & 27 & 29 & 27 & 205 \\
\hline 93 & Trade, Services and Investment & Retail Trade & 16 & 18 & 19 & 18 & 18 & 19 & 21 & 21 & 150 \\
\hline 94 & Trade, Services and Investment & Tourism, Restaurant, and Hotel & 12 & 14 & 13 & 15 & 18 & 15 & 24 & 22 & 133 \\
\hline 95 & Trade, Services and Investment & Advertising, Printing, and Media & 9 & 8 & 8 & 9 & 13 & 12 & 13 & 16 & 88 \\
\hline 96 & Trade, Services and Investment & Health Care & 1 & 1 & 3 & 2 & 4 & 6 & 3 & 5 & 25 \\
\hline 97 & Trade, Services and Investment & Computer and Services & 3 & 2 & 2 & 2 & 4 & 4 & 5 & 4 & 26 \\
\hline 98 & Trade, Services and Investment & Investment Company & 5 & 7 & 6 & 6 & 5 & 5 & 6 & 8 & 48 \\
\hline \multirow[t]{2}{*}{99} & Trade, Services and Investment & Others & 2 & 3 & 4 & 3 & 3 & 4 & 5 & 7 & 31 \\
\hline & & & 265 & 286 & 311 & 270 & 349 & 335 & 377 & 403 & 2596 \\
\hline
\end{tabular}

The finance sector was not included in the data, because (a) the policies of the financial sector differ from those of other sectors, and (b) besides the policy differences, the finance sector also generally pays greater dividends. In Indonesia, policies in the financial sector (in addition to referring to IDX regulations) are also based on the Financial Services Authority (OJK) regulations.

The equation model used in this study indicate in Table 2:

Table 2. Research Equation.

The first model: the propensity of manufacturing companies, compared to non-manufacturers, in cash dividend payouts versus not paying cash dividends. The scale of the variable in the predictor and response is binomial.

The second model: propensity to pay cash dividends, compared to not paying cash dividends, as determined by the percentage of institutional ownership. The scale of the variable in the predictor is a ratio and the response is binomial.

The third model: propensity to pay cash dividend as determined by the sector $\left(X_{1}\right)$ and the percentage of institutional ownership. The response variable scale is binomial, predictor $X_{1}$ is binomial, and $X_{2}$ is a ratio.

$$
\log \left(\frac{p}{1-p}\right)=\beta_{0}+\beta_{1} X_{1}
$$

$$
\log \left(\frac{p}{1-p}\right)=\beta_{0}+\beta_{1} X_{1}
$$

$$
\log \left(\frac{p}{1-p}\right)=\beta_{0}+\beta_{1} X_{1}+\beta_{2} X_{2}
$$


The 'propensity to pay cash dividends' was selected as a variable based on two considerations. First, this variable affects the influence of FCF on sectoral differences and agency problems regarding the use of opportunistic managerial cash. As such, it becomes more appropriate to use cash dividends compared to other variables such as stock dividends. Second, evidence suggesting the definite significant impact of the predictor variable on the dependent variable concerning dividend policies is still lacking. Thus, the current research decided to explore the propensity to pay cash dividends.

\section{Findings and Results}

In terms of the institutional ownership percentage based on propensity to pay cash dividends, the current findings reveal that, among companies with institutional ownership, as many as 1448 of them $(53.78 \%)$ did not pay dividends while the remaining 1148 companies $(44.22 \%)$ paid dividends. Table 3 depicts the differences in standard deviation, interquartile, and mean relative between the percentage of institutional ownership in companies that did not pay dividends and paid dividends.

Table 3. Data description: propensity to pay or not pay cash dividends based on institutional ownership.

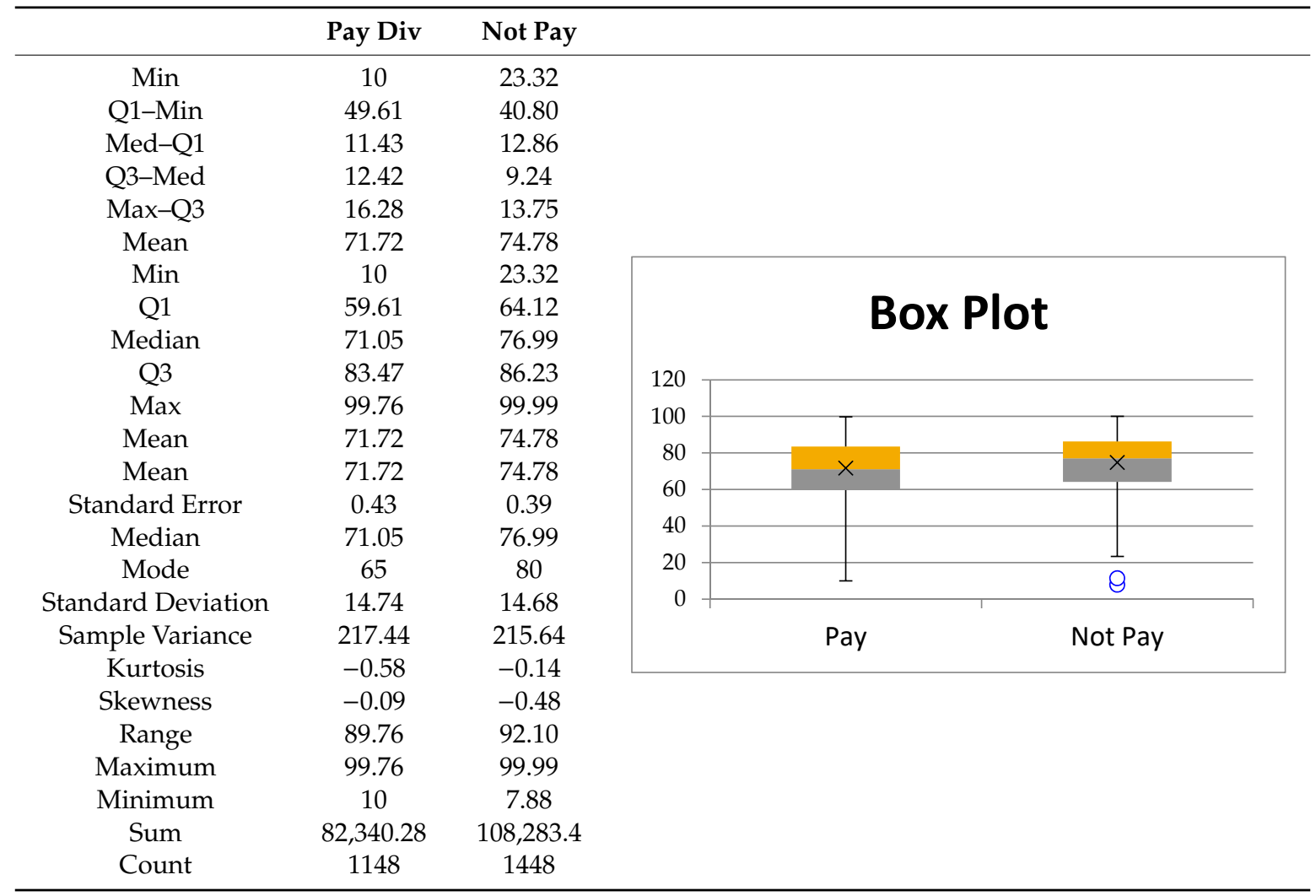

The data description of the percentage of institutional ownership by the manufacturing sector is as follows: (a) $34.78 \%$ comes from the manufacturing sector; (b) $65.22 \%$ comes from the non-manufacturing sector. Table 4 shows the variations in the average flat, interquartile, and standard deviation of the percentage of institutional ownership between the manufacturing and non-manufacturing companies (see Table 1).

Most companies, both those share DPS or not, have similar characteristics. Namely, the proportion of institutional ownership is greater than the average. As such, the ownership proportion tends to vary. The number of companies that distribute DPS has a proportion of institutional ownership that is greater than the average and more than those that do not distribute dividends. Similarly, companies that distribute DPS are more homogeneous in institutional ownership proportion than those that do not share DPS. Proposed provisional evidence is that companies tend to share DPS if they have sizeable 
institutional ownership and more concentrated institutional ownership structures. Further elaboration exploring the impact of institutional ownership concentration on DPS is provided [20].

The percentage of institutional ownership in the sectoral (manufacturing or other) category was more diverse than the propensity to pay dividends (or not) category. The background of the percentage of ownership of companies in the category of propensity to pay (or not pay) was relatively more homogeneous, with a more variable percentage of ownership intervals.

Table 4. Data descriptive: industry sectors (manufacturing or others) based on institutional ownership (\%).

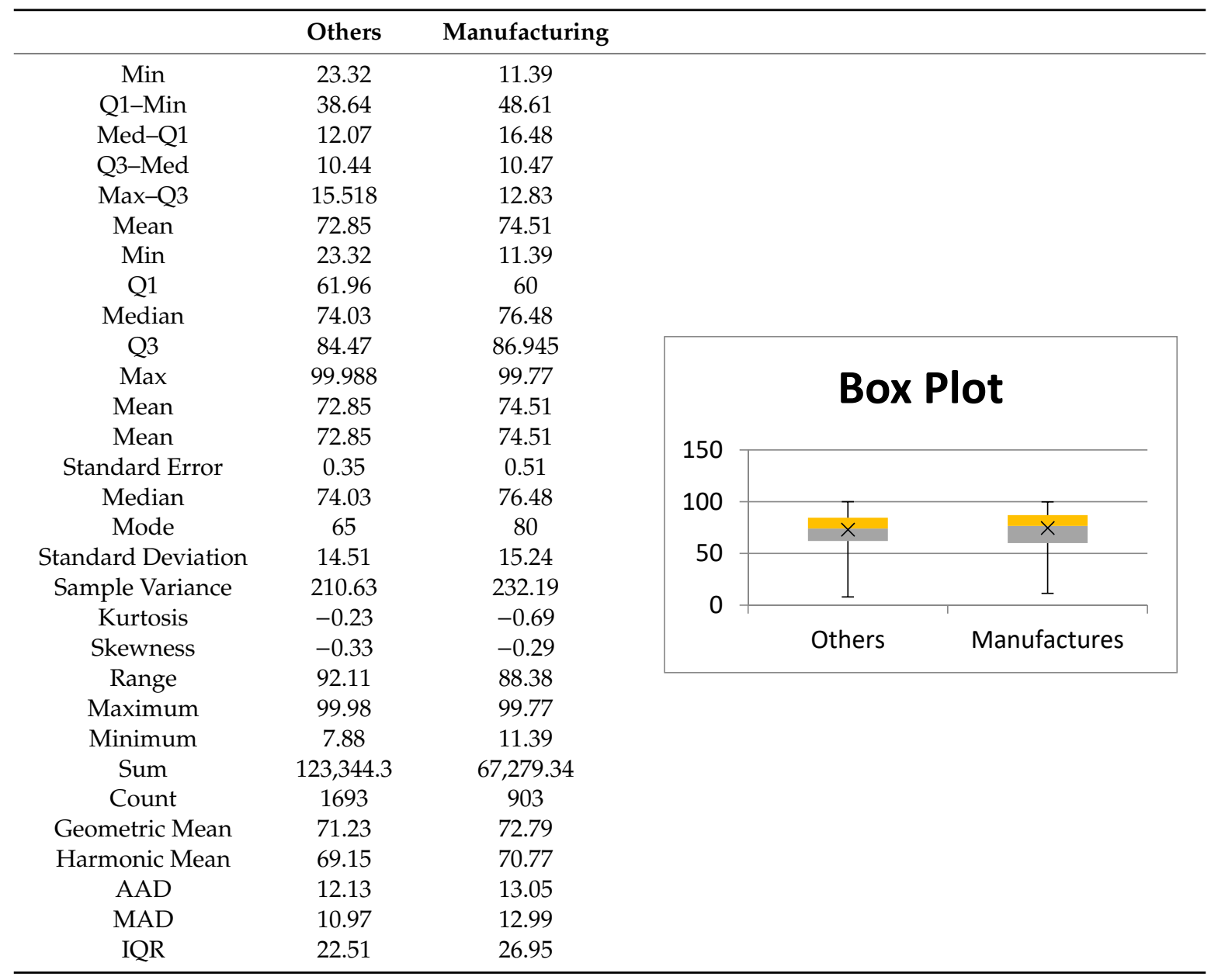

Central tendency, kurtosis, and skewness of manufacturing and non-manufacturing companies show coefficients with negative signs in Table 4. Both have several companies with institutional ownership compared to the average institutional ownership. Additionally, the proportion of institutional ownership is more widespread. In comparison, manufacturing companies have more institutional ownership than non-manufacturing companies and more concentrated ownership.

The FCF hypothesis has explained that dividend payments will reduce agency problems and limit overinvestment, thereby creating EPS growth. The correlation results (Table 5) show that EPS and DPS have a positive and significant correlation, so to eliminate this effect, EPS is used as a control variable.

Table 5. Correlation coefficient.

\begin{tabular}{cccc}
\hline & Ins Ownership & EPS & DPS \\
\hline Ins Ownership & 1 & & \\
EPS & $0.056(0.004)$ & 1 & \\
DPS & $0.055(0.005)$ & $0.616(0.000)$ & 1 \\
\hline
\end{tabular}


Testing the first model: Let $p$ be the proportion to pay dividend and $X$ be the percentage of institutional ownership. The equation and yield model for propensity is a logistic regression equation in Table 5, as follows:

$$
\log \left(\frac{p}{1-p}\right)=\beta_{0}+\beta_{1} X_{1} .
$$

Dividends, as the control variable, are divided into two: positive and negative EPS. An increase in institutional ownership will reduce the propensity to pay dividends. The results show that institutional ownership, with EPS as a control variable, has a significant negative effect on dividend payment propensity; the greater the institutional ownership, the smaller the proportion to pay dividends. Table 6 show odds ratios coefficients are 0.815 when the EPS is 4.307. This result indicates that companies with institutional ownership have a lower propensity to pay (or not pay) dividends. When the control and ownership functions are separate (agent-owner), managers will solely act based on their interests, therefore shareholders interest is not performed. However, when managers concurrently are shareholders, hence common interest appears and it will negatively affect debtholders. This situation encourages better market monitoring, according to the signaling hypothesis, and impact on non-institutional expected dividends [4].

Table 6. Logistic regression test model 1.

\begin{tabular}{cccccc}
\hline & Coeff b & s.e. & Wald & $p$-Value & Exp (b) \\
\hline Intercept & -0.586 & 0.262 & 5.005 & 0.025 & 0.556 \\
EPS & 1.460 & 0.099 & 219.485 & 0.000 & 4.307 \\
Inst & -0.204 & 0.072 & 8.138 & 0.004 & 0.815 \\
\hline
\end{tabular}

Managers, as shareholders, will make suboptimal investments to raise equity values without regard to company value. In this situation, the company prefers equity selection with less risk than debt. This evidence shows that companies can effectively monitor their finance with large and concentrated institutional ownership. Thus, there is no need to increase the role of dividends as a capital market monitoring mechanism. Marginal propensity to pay dividends based on institutional ownership (see Table 7) shows the difference between negative and positive EPS control variables. Marginal propensity to pay dividends is greater in the positive EPS than negative EPS. The marginal DPS probability is greater in the middle, because institutional ownership plays a more effective role in monitoring agency problems, compared to lower or larger levels of the middle. Managers take opportunistic actions to support overinvestment [20]. Consequently, even though large amount of institutional ownerships were recorded, the number of companies that distributed dividends remained small. This situation allows managers as shareholders and institutions to collaborate in reducing the propensity to pay dividends, even at a low level. Evidence of suboptimal investment through risky debt collaboration is performed between shareholders and managers to transfer the value of debtholders to shareholders.

Table 7. Marginal propensity to pay dividends.

\begin{tabular}{ccccccccc}
\hline EPS & Bin. Inst & Success & Failure & Total & p-Obs & p-Pred & Suc-Pred & Fail-Pred \\
\hline Negative & 25 & 1 & 2 & 3 & 0.333 & 0.312 & 0.936 & 2.064 \\
Negative & 50 & 12 & 25 & 37 & 0.324 & 0.270 & 9.987 & 27.013 \\
Negative & 75 & 72 & 248 & 320 & 0.225 & 0.232 & 74.101 & 245.899 \\
Negative & 100 & 86 & 350 & 436 & 0.197 & 0.197 & 85.976 & 350.024 \\
Positive & 25 & 1 & 2 & 3 & 0.333 & 0.661 & 1.984 & 1.016 \\
Positive & 50 & 26 & 36 & 62 & 0.419 & 0.614 & 38.083 & 23.917 \\
Positive & 75 & 526 & 361 & 887 & 0.593 & 0.565 & 500.997 & 386.003 \\
Positive & 100 & 424 & 424 & 848 & 0.500 & 0.514 & 435.935 & 412.065 \\
& & 1148 & 1448 & 2596 & & & 1148 & 1448 \\
\hline
\end{tabular}


Developing countries, such as Indonesia, show a high asymmetry of information, resulting in dividends as signals sent to the capital market $[53,54]$. This shows that institutional ownership support can replace the role of dividends. Most companies are owned by finance companies, invested in the form of shares. This situation results in a reduction in dividends to the market. Dividends can be used to reduce information asymmetry between managers and shareholders by conveying information about the company's future prospects.

Second Model Testing: Let $p$ be the proportion to pay dividends and $X$ indicate the industrial sector ( $X=1$ is manufacturing and $X=0$ is other or non-manufacturing) and $X=$ success is pay dividend and $X=$ failure is other. The equation model for propensity is a logistic regression equation, as follows:

$$
\log \left(\frac{p}{1-p}\right)=\beta_{0}+\beta_{1} X_{1}
$$

Both sectors (i.e., manufacturing and non-manufacturing) have a smaller cash dividend proportion, compared to those that do not pay dividend. Companies originating from the manufacturing and non-manufacturing sectors have a greater tendency to not pay cash dividends (coefficient smaller than 1, as shown in Table 8). Inference tests show that these results are significant.

Table 8. Logistic binary regression.

\begin{tabular}{cccccc}
\hline Sector & Success & Failure & Total & p-Obs & p-Pred \\
\hline Non-Man & 704 & 989 & 1693 & 0.416 & 0.416 \\
Man & 435 & 468 & 903 & 0.482 & 0.482 \\
& 1139 & 1457 & 2596 & & \\
\hline & coeff b & s.e. & Wald & $p$-value & $\exp (\mathrm{b})$ \\
Intercept & -0.340 & 0.050 & 47.518 & 0.000 & 0.712 \\
Sector & 0.267 & 0.083 & 10.365 & 0.002 & 1.306 \\
\hline
\end{tabular}

The odds coefficient shows the ratio of probability of propensity to pay, or not pay, dividends. Propensity to pay dividends, compared to not paying dividends, in manufacturing companies was 1.3057 or 1.31 times greater than in non-manufacturing companies. This indicates that the propensity of manufacturing companies to pay dividends is $31 \%$ more than non-manufacturing companies. Free cash flow for manufacturing companies was greater than that of non-manufacturing companies. This is because the availability of free cash flow is higher than the working capital requirements; thus, increasing the propensity to pay cash dividends. Manufacturing companies in Indonesia originate from the basic industry and chemical, miscellaneous, and consumer goods industrial sectors in the 2011-2018 observation period, which had higher average earnings compared to the non-manufacturing sectors.

Free cash flow is the result of a reduction in capital expenditure and operational cash flow. Free cash flow increases with increased revenue, increased efficiency, and reduced costs. Therefore, we used the measurement of earnings per share (EPS) annually. This result was in line with previous research, which stated that each sector has different characteristics, and consequently differing free cash flows and dividend policies [12,22]. This finding shows support for the FCF agency theory, which states that companies in different industrial sectors have FCF variations. Hence, the agency problems that occur are also different. Therefore, the use of dividends as a bonding mechanism also differs with respect to the industrial sector.

The agency theory hypothesis of free cash flow explains that with FCF's availability, managers can act in their own interests and put aside the nexus contract with shareholders. The company's industrial sector has different characteristics that result in different suboptimal investment opportunities, where overinvestment can be caused by the level of risk, underinvestment in asset ownership, and investment opportunities, which in further research is developed in other company characteristics. Manufacturing companies have a propensity to pay a dividend of $31 \%$ more than non-manufacturing. 
Data from manufacturing and non-manufacturing companies with institutional ownership show evidence of differences in propensity to pay dividends. This situation proves that manufacturing companies have greater suboptimal investment problems, so that the opportunity to distribute dividends as a mechanism for monitoring capital markets is greater. Manufacturing companies having greater propensity is an indication of preferring monitoring from the capital market compared to non-manufacturing. Firm characteristics affecting the FCF agency problem; because there is no equity and concentrated ownership, agency problems are not found in SMEs [49].

Third Model Testing: Let $p$ be the dividend payment propensity, $X_{1}$ be the percentage of institutional ownership, and $X_{2}$ be a sectoral indicator $\left(X_{2}=1\right.$ indicates manufacturing and $X_{2}=0$ indicates otherwise). The equation and yield model and results (Table 9 ) for propensity is a logistic regression equation, as follows:

$$
\log \left(\frac{p}{1-p}\right)=\beta_{0}+\beta_{1} X_{1}+\beta_{2} X_{2}
$$

Table 9. Logistic regression test model 2.

\begin{tabular}{ccccccc}
\hline Ins Ownership & Sectors & Payout & Not & Total & p-Obs & p-Pred \\
\hline 25 & 0 & 2 & 3 & 5 & 0.4 & 0.565507 \\
50 & 0 & 27 & 46 & 73 & 0.369863 & 0.503334 \\
75 & 0 & 402 & 422 & 824 & 0.487864 & 0.441058 \\
100 & 0 & 273 & 518 & 791 & 0.345133 & 0.380583 \\
25 & 1 & 0 & 1 & 1 & 0 & 0.635471 \\
50 & 1 & 10 & 16 & 26 & 0.384615 & 0.5758 \\
75 & 1 & 192 & 191 & 383 & 0.501305 & 0.513834 \\
100 & 1 & 233 & 260 & 493 & 0.472617 & 0.451439 \\
& & 1139 & 1457 & 2596 & & \\
Intercept & 0.51375 & 0.238717 & 4.631678 & 0.031387 & 1.671548 & \\
Ins Owner & -0.01001 & 0.002743 & 13.30943 & 0.000264 & 0.990042 & \\
Sectors & 0.292218 & 0.083411 & 12.27352 & 0.000459 & 1.339395 & \\
\hline
\end{tabular}

The test results show that the probability of paying dividends was significantly negatively influenced by institutional ownership and significantly positively influenced by the sectoral indicator. The higher the percentage of institutional ownership, the lower the propensity to pay dividends (with an odds ratio close to 1). Companies with institutional ownership had the same probability of propensity to pay dividends or not. Companies in the manufacturing sector had a probability of paying cash dividends (compared to not paying) 1.33 times greater than that of the non-manufacturing sector. Therefore, a decrease in institutional ownership and sector status (i.e., manufacturing or non-manufacturing) could increase the propensity to pay cash dividends. In the manufacturing sector, propensity odds were greater than in non-manufacturing sectors, and higher institutional ownership implied better monitoring resources, compared to the capital market. Therefore, manufacturing companies with institutional ownership characteristics had a lower propensity to pay a cash dividend.

Non-manufacturing sector companies with increasingly large and concentrated institutional ownership had a lower propensity to pay dividends. As shareholders, managers tend to make suboptimal investments that can pose a problem in the manufacturing sector by increasing the proportion to pay dividends. A large proportion of concentrated institutional ownership simultaneously reduces dividends, where in Indonesia, they have the resources to monitor. This research concludes that institutional ownership and industrial characteristics are an alternative mechanism to restrict managerial power discretion over FCF through equity. Institutional ownership in Indonesia has excessive resources for monitoring, therefore, it does not require a capital market. However, manufacturing companies with suboptimal investment problems, which are greater than non-manufacturing, always need a capital market monitoring mechanism, through dividends. 
The result of the research indicates that open innovation potential acquires long-term shareholder value relationships. Companies that apply open innovation can distribute dividends continuously, therefore shareholder and company relationships able to exist for more than 60 years [45]. Research findings show that listed companies in the manufacturing sector on the Indonesia Stock Exchange tend to obtain greater benefits of open innovation adoption, therefore the propensity to pay dividends is greater than non-manufacturing companies [44]. However, companies with institutional ownership are not positively related to dividend, as a result of open innovation adoption. Companies with institutional ownership the propensity to pay dividends decreases. Institutional ownership focuses on short-term compared to long-term R\&D activities, and innovation depends on financial constraints [55]. This situation encourages companies with institutional ownership to restrict long-term funding, in contrast, external cooperation requires financing to adopt open innovation, the impact is a decrease in the propensity to pay dividends. Innovation is prominent in the organization due to the existence of open innovation that can improve company performance. Open innovation facilitates companies to achieve goals based on their vision and mission, through a business strategy that can achieve production efficiency and effectiveness. The change from close innovation to open innovation involves an inter-organizational network of the organizational structure, evaluation process, and knowledge system management [56]. Culture has an important role in the organization's improvement, especially in innovation to deal with a company dynamic environment phenomenon, therefore encouraging businesses to adapt through innovation. Open innovation expedites the achievement of corporate culture goals in an organization which consists of three aspects, namely entrepreneurship, intrapreneurship, and organization entrepreneurship for open dynamics innovation [57]. The organizational change mechanism, towards open innovation, should appropriate several stages, namely the need for a balance in changing innovation. When the company can balance determining aspects of the organization, this will lead to the success of conducting open innovation [58]. There is a paradox that arises when open innovation is performed by companies. When the company is successful in conducting open innovation, theoretically it will facilitate the company to achieve its goals. However, open innovation is contrary to the commercialization of innovation which requires protection to fortify oneself. When innovation is not protected it can be imitated by other companies, therefore innovations executed openly have advantages and disadvantages [59].

The results of this study indicate that open innovation is capable of increasing company revenue due to cost reduction. The company cost of innovation requires a large investment, therefore company profit that should be distributed through dividends to shareholders is reduced [49]. The problem of lessening a portion of dividends due to open innovation can be overcome through the relationship between the company and external parties [50]. The organizational environment includes the company, government, and the community. Open innovation can be conducted with the collaboration of a quadruple helix. The cooperation of a quadruple helix is able to reduce research costs in open innovation, and therefore able to increase the percentage of dividend distribution. Open innovation is beneficial, both for the company and shareholder, to achieve targets and goals, and to obtain higher profit [48]. Open innovation is a company's effort to increase revenue and profit. Open innovation is a company's effective strategy to obtain consistent profits. Open innovation has broad and positive implications for the quadruple helix.

\section{Conclusions}

There are differences in the characteristics of dividend distribution in developed and developing countries. In this study, we examined the effects of institutional ownership and different industrial sectors on the proportion of cash dividends in Indonesia (as a developing country). Institutional ownership of a company has a negative influence on its propensity to pay cash dividends. In general, the three models that have been tested showed significant results on the proportion to pay cash dividends in Indonesia, where manufacturing companies had higher odds of paying cash dividends than non-manufacturing companies. Manufacturing companies tend to grow more, with consequent greater FCF, than non-manufacturing companies, causing them to have a higher propensity to pay 
cash dividends. Therefore, the propensity to pay cash dividends is comprehensively determined by institutional ownership and differences in the industrial sectors.

As a practical implication, we can provide investors with objective advice regarding the determinants of propensity to pay cash dividends. For example, when making an investment decision, one should consider the characteristics of the sector and the extent to which a company has institutional ownership. The limitation of the study is that the generality of the findings is still considered weak due to the highly differing characteristics of the firms.

Author Contributions: S.M. is generating an idea for this research, he proposes and contributing for the introduction. A.Y. arranges and develop literature review, method, and conclusion. R.S.W. analyzes data and contributes to the discussion. A.P.W. develops enrichment open innovation in literature review and discussion. All authors have read and agreed to the published version of the manuscript.

Funding: This research was funded by the Indonesian Ministry of Education and Culture through Research Grant Universitas Negeri Semarang in 2020.

Conflicts of Interest: There is no conflict of interest regarding this research.

\section{References}

1. Jensen, M.C. Agency Costs of Free Cash Flow, Corporate Finance, and Takeovers Agency Costs of Free Cash Flow, Corporate Finance, and Takeovers. Am. Econ. Rev. 1999. [CrossRef]

2. Easterbrook, F.H. Two Agency-Cost Explanations of Dividends. Am. Econ. Rev. 1984, 74, 650-659.

3. Panousi, V.; Papanikolaou, D. Investment, Idiosyncratic Risk, and Ownership. J. Financ. 2012, 67, 1113-1148. [CrossRef]

4. La Porta, R.; Lopez-De-Silanes, F.; Shleifer, A.; Vishny, R. Investor protection and corporate governance. J Financ. Econ. 2000, 58, 3-27. [CrossRef]

5. Shleifer, A.; Vishny, R.W. Management entrenchment. The case of manager-specific investments. J. Financ. Econ. 1989, 25, 123-139. [CrossRef]

6. Chen, J.; Hong, H.; Stein, J.C. Forecasting crashes: Trading volume, past returns, and conditional skewness in stock prices. J. Fnanc. Econ. 2001, 61, 345-381. [CrossRef]

7. Myers, S.C. Determinants of corporate borrowing. J. Fnanc. Econ. 1977, 5, 147-175. [CrossRef]

8. Almeida e Brito, J.G.; John, K. Leverage and Growth Opportunities: Risk-Avoidance Induced by Risky Debt. SSRN Electron. J. 2005. [CrossRef]

9. Nguyen Trong, N.; Nguyen, C.T. Firm performance: The moderation impact of debt and dividend policies on overinvestment. J. Asian Bus. Econ. Stud. 2020. [CrossRef]

10. Décamps, J.P.; Mariotti, T.; Rochet, J.C.; Villeneuve, S. Free Cash Flow, Issuance Costs, and Stock Prices. J. Fnanc. 2011, 66, 1501-1544. [CrossRef]

11. Dickinson, V. Cash flow patterns as a proxy for firm life cycle. Acc. Rev. 2011, 86, 1969-1994. [CrossRef]

12. Fleming, J.; Emery, D.R.; Finnerty, J.D. Corporate Financial Management. J. Fnanc. 1997, 52, 1742. [CrossRef]

13. Ang, J.S.; Cole, R.; Lin, J.W. Agency costs and ownership structure. In Corporate Governance and Corporate Finance: A European Perspective; Routledge: London, UK, 2007.

14. Short, H.; Zhang, H.; Keasey, K. The link between dividend policy and institutional ownership. J. Corp. Financ. 2002, 8, 105-122. [CrossRef]

15. Truong, T.; Heaney, R. Largest shareholder and dividend policy around the world. Q. Rev. Econ. Financ. 2007, 47, 667-687. [CrossRef]

16. Shaheen, R. Effect of Institutional and Insider Ownership on Dividend Policy: Evidence from Pakistan. J. Bus. Tour. 2018, 4, 181-192.

17. Pinto, G.; Rastogi, S. Sectoral Analysis of Factors Influencing Dividend Policy: Case of an Emerging Financial Market. J. Risk Financ. Manag. 2019, 12, 110. [CrossRef]

18. Gillan, S.L.; Starks, L.T. Corporate Governance, Corporate Ownership, and the Role of Institutional Investors: A Global Perspective. SSRN Electron. J. 2003. [CrossRef]

19. Chung, R.; Firth, M.; Kim, J.B. FCF agency costs, earnings management, and investor monitoring. Corp. Ownersh. Control 2005, 2. [CrossRef] 
20. Chang, K.; Kang, E.; Li, Y. Effect of institutional ownership on dividends: An agency-theory-based analysis. J. Bus. Res. 2016, 69, 2551-2559. [CrossRef]

21. Al-malkawi, H.N. Factors Influencing Corporate Dividend Decision: Evidence from Jordanian Panel Data. Int. J. Bus. 2008, 13, 177-195.

22. Giriati, Z. Free Cash Flow, Dividend Policy, Investment Opportunity Set, Opportunistic Behavior and Firm's Value: (A Study About Agency Theory). Procedia Soc. Behav. Sci. 2016, 219, 248-254. [CrossRef]

23. Wang, G.Y. The Impacts of Free Cash Flows and Agency Costs on Firm Performance. J. Serv. Sci. Manag. 2010, 3, 408-418. [CrossRef]

24. Griffin, P.A.; Lont, D.H.; Sun, Y. Agency problems and audit fees: Further tests of the free cash flow hypothesis. Acc. Financ. 2010, 50, 321-350. [CrossRef]

25. Manneh, M.A.; Naser, K. Determinants of Corporate Dividends Policy: Evidence from an Emerging Economy. Int. J. Econ. Financ. 2015, 7. [CrossRef]

26. Kouki, M.; Guizani, M. Ownership structure and dividend policy evidence from the Tunisian stock market. Eur. J. Sci. Res. 2009. [CrossRef]

27. Jain, R. Institutional and individual investor preferences for dividends and share repurchases. J. Econ. Bus. 2007, 59, 406-429. [CrossRef]

28. Abdelsalam, O.; El-Masry, A.; Elsegini, S. Board composition, ownership structure and dividend policies in an emerging market: Further evidence from CASE 50. Manag. Financ. 2008, 34, 953-964. [CrossRef]

29. Amihud, Y.; Li, K. The declining information content of dividend announcements and the effects of institutional holdings. J. Financ. Quant. Anal. 2006, 41, 637-660. [CrossRef]

30. Gombola, M.J.; Liu, F.-Y. The Signaling Power of Specially Designated Dividends. J. Financ. Quant. Anal. 1999, 34, 409. [CrossRef]

31. Taleb, L. Dividend Policy, Signaling Theory: A Literature Review. SSRN Electron. J. 2019. [CrossRef]

32. Elfakhani, S. An Empirical Examination of the Information Content of Balance Sheet and Dividend Announcements: A Signaling Approach. J. Financ. Strateg. Decis. 1995, 8, 65-76.

33. Lin, T.J.; Chen, Y.P.; Tsai, H.F. The relationship among information asymmetry, dividend policy and ownership structure. Financ. Res. Lett. 2017, 20,1-12. [CrossRef]

34. Balachandran, B.; Faff, R.; Nguyen, T.A. The intra-industry impact of special dividend announcements: Contagion versus competition. J. Multinatl. Financ. Manag. 2004, 14, 369-385. [CrossRef]

35. Dubey, R.; Bag, S.; Ali, S.S.; Venkatesh, V.G. Green purchasing is key to superior performance: An empirical study. Int. J. Procure. Manag. 2013, 6, 187-210. [CrossRef]

36. Bogers, M.; Chesbrough, H.; Moedas, C. Open innovation: Research, practices, and policies. Calif. Manag. Rev. 2018, 60, 5-16. [CrossRef]

37. Trott, P.; Hartmann, D.A.P. Why 'open innovation' is old wine in new bottles. Br. J. Radiol. 2009, 83, $1023-1028$. [CrossRef]

38. Goo, J.J.; Heo, J.Y. The impact of the regulatory sandbox on the fintech industry, with a discussion on the relation between regulatory sandboxes and open innovation. J. Open Innov. Technol. Mark. Complex. 2020, 6, 43. [CrossRef]

39. Naqshbandi, M.M. Organizational Characteristics and Engagement in Open Innovation: Is There a Link? Glob. Bus. Rev. 2018, 19 (Suppl. 3), S1-S20. [CrossRef]

40. Hicheon, K.; Heechun, K.; Peggy, M.L. Ownership structure and the relationship between financial slack and R\&D investments: Evidence from Korean Firms. Organ. Sci. 2008, 19, 404-418.

41. Clark, T. Strategy viewed from a management fashion perspective. Eur. Manag. Rev. 2004, 1, $105-111$. [CrossRef]

42. Boh, W.F.; Huang, C.J.; Wu, A. Investor experience and innovation performance: The mediating role of external cooperation. Strateg. Manag. J. 2020, 41, 124-151. [CrossRef]

43. Chen, V.Z.; Li, J.; Shapiro, D.M.; Zhang, X. Ownership structure and innovation: An emerging market perspective. Asia Pac. J. Manag. 2014, 31,1-24. [CrossRef]

44. Noh, Y. Financial effects of open innovation in the manufacturing industry. Manag. Decis. 2015, 53, 1527-1544. [CrossRef]

45. Miglietta, N.; Battisti, E.; Garcia-Perez, A. Shareholder value and open innovation: Evidence from Dividend Champions. Manag Decis. 2018, 56, 1384-1397. [CrossRef] 
46. Tajudeen, F.P.; Jaafar, N.I.; Sulaiman, A. External technology acquisition and external technology exploitation: The difference of open innovation effects. J. Open Innov. Technol. Mark. Complex. 2019, 5, 5-7. [CrossRef]

47. Gassmann, O.; Enkel, E.; Chesbrough, H. The future of open innovation. R D Manag. 2010, 40, $213-221$. [CrossRef]

48. Uribe-Echeberria, R.; Igartua, J.I.; Lizarralde, R. Implementing open innovation in research and technology organisations: Approaches and impact. J. Open Innov. Technol. Mark. Complex. 2019, 5. [CrossRef]

49. Pervan, S.; Al-Ansaari, Y.; Xu, J. Environmental determinants of open innovation in Dubai SMEs. Ind. Mark. Manag. 2015, 50,60-68. [CrossRef]

50. Afonso, O.; Monteiro, S.; Thompson, M. A growth model for the quadruple helix. J. Bus. Econ. Manag. 2012, 13, 849-865. [CrossRef]

51. Chung, K.H.; Zhang, H. Corporate governance and institutional ownership. J. Financ. Quant. Anal. 2011, 46, 247-273. [CrossRef]

52. Wardhana, L.I.; Tandelilin, E. Do we need a mandatory dividend regulation? The case of the Indonesian capital market. Gadjah Mada Int. J. Bus. 2018, 20, 33. [CrossRef]

53. Cheryta, A.M.; Moeljadi; Indrawati, N.K. The Effect of Leverage, Profitability, Information Asymmetry, Firm Size on Cash Holding and Firm Value of Manufacturing Firms Listed at Indonesian Stock Exchange. Int. J. Res. Bus. Stud. Manag. 2017. [CrossRef]

54. Mustaruddin, M.; Aristya, D.; Wendy, W.; Anwar, A. Asymmetric information and capital structure: Empirical evidence from Indonesia Stock Exchange. Int. J. Econ. Financ. Issues 2017, 7, 8-15.

55. Schain, J.P.; Stiebale, J. Innovation, institutional ownership and financial constraints. Empir. Econ. 2020. [CrossRef]

56. Chiaroni, D.; Chiesa, V.; Frattini, F. Unravelling the process from Closed to Open Innovation: Evidence from mature, asset-intensive industries. R. Manag. 2010, 40, 222-245. [CrossRef]

57. Yun, J.H.J.; Zhao, X.; Jung, K.H.; Yigitcanlar, T. The culture for open innovation dynamics. Sustainability 2020, 12, 5076. [CrossRef]

58. Yun, J.H.J.; Won, D.K.; Park, K.B. Entrepreneurial cyclical dynamics of open innovation. J. Evol. Econ. 2018, 28, 1151-1174. [CrossRef]

59. Laursen, K.; Salter, A.J. The paradox of openness: Appropriability, external search and collaboration. Res. Policy 2014, 43, 867-878. [CrossRef]

(C) 2020 by the authors. Licensee MDPI, Basel, Switzerland. This article is an open access article distributed under the terms and conditions of the Creative Commons Attribution (CC BY) license (http://creativecommons.org/licenses/by/4.0/). 